\title{
Warming the phycosphere: differential effect of temperature on the use of diatom-derived carbon by two copiotrophic bacterial taxa
}

\author{
Nestor Arandia-Gorostidi ${ }^{1,2}$, Laura Alonso-Sáez ${ }^{2,3}$, Hryhoriy Stryhanyuk ${ }^{4}$, Hans H. Richnow ${ }^{4}$, Xosé \\ Anxelu G. Morán ${ }^{5}$, Niculina Musat ${ }^{4}$ \\ ${ }^{1}$ Department of Earth System Science, Stanford University, Stanford, CA, (USA). Tel: +1 (650) 4988123 \\ ${ }^{2}$ Instituto Español de Oceanografía, Centro Oceanográfico de Gijón/Xixón, Av. Príncipe de Asturias 70 \\ bis 33212, Gijón/Xixón, Asturias (Spain). Tel: +34 985309780 \\ ${ }^{3}$ AZTI, Marine Research Division, Txatxarramendi Irla s/n, 48395 Sukarrieta, Bizkaia (Spain), Tel: +34 \\ 946574000 \\ ${ }^{4}$ Helmholtz Centre for Environmental Research - UFZ, Department of Isotope Biogeochemistry, \\ Permoserstraße 15, 04318 Leipzig (Germany) Tel: +49 (0) 3412354656 \\ ${ }^{5}$ King Abdullah University of Science and Technology (KAUST), Red Sea Research Center, Biological \\ and Environmental Sciences and Engineering Division, 23955 Thuwal (Saudi Arabia). Tel: +966 (0) 12 \\ 8082455
}

Corresponding authors:

Dr. Nestor Arandia-Gorostidi

Stanford University

Department of Earth System Science

Green Earth Sciences Building

367 Panama St., Room 129

Stanford, CA 94305-4216

Phone: +1 6504988123Email:

n.arandia86@gmail.com
Dr. Niculina Musat

Helmholtz Centre for Environmental Research UFZ

Permoserstrasse 15

04318 Leipzig

Phone +49 (0) 3412354656

Email: niculina.musat@ufz.de

Running title: Effect of temperature in the bacterial DOC uptake

This article has been accepted for publication and undergone full peer review but has not been through the copyediting, typesetting, pagination and proofreading process which may lead to differences between this version and the Version of Record. Please cite this article as doi: $10.1111 / 1462-2920.14954$ 


\section{Significance Statement}

Phytoplankton-derived exudates represent the main carbon source for heterotrophic bacteria in coastal waters. During microphytoplankton blooms, some fast-growing bacterial groups colonize the phycosphere of microphytoplankton cells, which provides them with a faster access to recently fixed DOC. Ocean warming may alter the bacterial cell-specific uptake of algal-derived C, with important biogeochemical implications, but quantifying C fluxes of microphytoplankton-associated bacteria is challenging as it requires resolving microbial cell activities below the microscale spatial level. Using nanoSIMS analysis, we quantified the impact of experimental warming on algalderived C uptake by two model copiotrophic taxa (Rhodobacteraceae and Flavobacteria), which were abundant components of the algal/particle-associated fraction year-round at a coastal station of the Bay of Biscay. We found that Flavobacteria were the main contributor to total $\mathrm{C}$ uptake under high diatom abundance, and experimental warming enhanced their uptake activity up to 6fold. 


\section{Summary}

Heterotrophic bacteria associated with microphytoplankton, particularly those colonizing the phycosphere, are major players in the remineralization of algal-derived carbon. Ocean warming might impact DOC uptake by microphytoplankton-associated bacteria with unknown biogeochemical implications. Here, by incubating natural seawater samples at 3 different temperatures we analyzed the effect of experimental warming on the abundance and $\mathrm{C}$ and $\mathrm{N}$ uptake activity of Rhodobacteraceae and Flavobacteria, two bacterial groups typically associated with microphytoplankton. Using NanoSIMS single-cell analysis we quantified the temperaturesensitivity of these two taxonomic groups to the uptake of algal-derived DOC in the microphytoplankton-associated fraction with ${ }^{13} \mathrm{C}$-bicarbonate and ${ }^{15} \mathrm{~N}$-leucine as tracers. We found

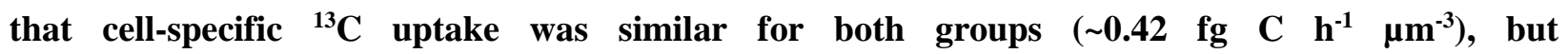
Rhodobacteraceae were more active in ${ }^{15} \mathrm{~N}$-leucine uptake. Due to the higher abundance of Flavobacteria associated with microphytoplankton, this group incorporated 4-fold more carbon than Rhodobacteraceae. Cell-specific ${ }^{13} \mathrm{C}$ uptake was influenced by temperature, but no significant differences were found for ${ }^{15} \mathrm{~N}$-leucine uptake. Our results show that the contribution of Flavobacteria and Rhodobacteraceae to C assimilation increased up to 6-fold and 2-fold, respectively, with an increase of $3^{\circ} \mathrm{C}$ above ambient temperature, suggesting that warming may differently affect the contribution of distinct copiotrophic bacterial taxa to carbon cycling.

\section{Introduction}

Marine phytoplankton contribute 46\% of the biosphere’s net primary production (Field, 1998; Behrenfeld et al., 2001) and represent one of the most important sources of dissolved organic carbon (DOC) 
(Norrman et al., 1995; Moran, 2015). In particular, coastal microphytoplankton blooms dominated by fast growing diatoms are responsible for a major share of global primary production (Joiris et al., 1982; Caffrey et al., 1998). DOC compounds released during these blooms are actively taken up by heterotrophic bacteria (Chrost and Faust, 1983; Meon and Kirchman, 2001), which can i) transfer this organic matter to higher trophic levels through the microbial loop, ii) convert it into more refractory carbon or iii) release it to the atmosphere as $\mathrm{CO}_{2}$ through bacterial respiration (Azam, 1998; Jiao et al., 2010). Trophic interactions between bacteria and microphytoplankton are influenced by the composition of bacterial communities (Pinhassi et al., 2004; Grossart et al., 2005; Klindworth et al., 2014), as distinct taxonomic groups have different roles in the uptake of algal-derived DOC (Teeling et al., 2012). Some environmental parameters such as temperature may also have a key impact on these interactions, by promoting the $\mathrm{C}$ fluxes between both bacterial and phytoplankton communities (Arandia-Gorostidi et al., 2017b).

Remarkably, most of the studies addressing the bacterial-phytoplankton coupling have focused exclusively on free-living communities (Duarte et al., 2005; Hoppe et al., 2008; von Scheibner et al., 2014), overlooking the heterotrophic bacteria found in the vicinity of microphytoplankton cells, i.e., the phycosphere. The phycosphere is defined as the region immediately surrounding the algal cells, which is highly enriched with organic molecules exuded by the microphytoplankton cell (Seymour et al., 2017). It has been proposed that bacteria associated with microphytoplankton may have stronger physical and metabolic interactions with microphytoplankton cells than their free-living counterparts (Rooney-Varga et al., 2005; Grossart et al., 2007), since the uptake of an important fraction of the microphytoplankton exudates takes place in this limited area where bacteria have fast access to recently fixed C (Smriga et al., 2016). A previous study has indicated that increasing temperatures may have a higher impact on the C 
uptake by bacteria associated to phytoplankton than by their free-living counterparts (Arandia-Gorostidi et al., 2017b). However, the temperature-response of different bacterial taxa to the uptake of DOC is largely unknown, mostly due to the difficulties in coupling taxonomic identification and cell-specific substrate uptakes in small-scale environments such as the phycosphere.

In this work we combined taxonomic identification by CARD-FISH with stable isotope probing and nanoSIMS analysis to determine the effect of experimental warming on the cell-specific DOM assimilation-rates of two ecologically relevant bacterial groups typically found in association with microphytoplankton: Flavobacteria and Rhodobacteraceae (Buchan et al., 2005; Gómez-Pereira et al., 2010; Fernández-Gómez et al., 2013; Buchan et al., 2014). As explained in Buchan et al. (2014), the Rhodobacteraceae family includes the Roseobacter clade, which contains a large number of genera (>50), and marine Flavobacteria contains representatives of the Flavobaceriales order, including two families (Flavobacteriaceae and Cryomophacaeae). Both, Rhodobacteraceae and Flavobacteria groups have been described as major players in the use and remineralization of algal-derived DOC (Buchan et al., 2014), but their relative contribution to the consumption of photosynthates is unknown. Coinciding with high diatom abundance at in situ conditions, we quantified the single-cell uptake activity of both leucine and algal-derived DOC uptake by both bacterial taxonomic groups in order to assess differences in their potential contribution to carbon and nitrogen fluxes under increased temperature conditions. 


\section{Results}

Environmental analysis of particle-associated bacterial taxa under different chlorophyll a conditions

In order to identify bacterial taxa that were preferentially associated to particles (including microphytoplankton cells), we analysed the bacterial community composition in the particle-associated (fraction $>3 \mu \mathrm{m}$ ), and the free-living fraction (fraction between $3 \mu \mathrm{m}$ and $0.22 \mu \mathrm{m}$ ). In a total of 11 samples collected during 3-years (2009-2012), encompassing from relatively low $\left(0.42 \mu \mathrm{g} \mathrm{L}{ }^{-1}\right)$ to high $\left(1.81 \mu \mathrm{g} \mathrm{L}^{-1}\right) \mathrm{Chl} a$ concentrations, we found that in the particle-associated fraction the Flavobacteriales order (within Flavobacteria) was generally the most abundant group (Figure 1B). Its average contribution to total abundance (22\%) was significantly higher than Rhodobacterales (11\%, Wilcoxon test, pvalue=0.02), while the latter was more abundant than other groups such as Alteromonadales (4.6\%, Wilcoxon test, p-value=0.008). Occasionally, other groups such as Sphingomonadales (Flavobacteria) were also abundant (up to 38.6\% in May 2010), although their average contribution (6.1\%) was clearly below Rhodobacterales and Flavobacteriales. While different taxa dominated the particle-associated and free-living communities (Supplementary Figure S1), the difference between the relative abundance of Flavobacteriales and Rhodobacterales was not significant.

Experimentally induced growth of microphytoplankton and bacterial communities in temperaturecontrolled experiments

To determine the temperature sensitivity of growth of microphytoplankton and microphytoplanktonassociated bacteria, we carried out 3 temperature-controlled incubation experiments in January, February and March 2014 using natural seawater. In situ analysis of environmental variables showed similar temperatures in the three months $\left(12.5\right.$ to $\left.13.0^{\circ} \mathrm{C}\right)$, while the initial chlorophyll $a$ concentration varied 
substantially, from ca. $1 \mu \mathrm{g} \mathrm{L} \mathrm{L}^{-1}$ in January and February to $5.4 \mu \mathrm{g} \mathrm{L}^{-1}$ in March (Supplementary figure S2A), which was the highest value measured during 3 years sampling at the study site. Accordingly, the in situ abundance of microphytoplankton in March was one order of magnitude higher as compared to January and February.

We followed the growth of phytoplankton in the three experiments, until the abundance of phytoplankton cells stabilized in the incubations, and before they started declining (4, 5, 1 days in January, February and March, respectively). We observed a substantial increase in the growth of microphytoplankton in the ambient temperature treatment of January and February (from ca. $20 \pm 7$ cells mL $\mathrm{mL}^{-1}$ to 3150 and 2378 cells $\left.\mathrm{mL}^{-1}\right)$. Although in situ microphytoplankton abundance in March was highest (144 \pm 9 cells $\left.\mathrm{mL}^{-1}\right)$ only an slight increase was observed after $12 \mathrm{~h}$ of incubation (to $165 \pm 15$ cells $\mathrm{mL}^{-1}$, Figure 2 ), followed by a decrease in phytoplankton abundance, indicating that the microphytoplankton community sampled in March could have been already decaying.

The community composition of the microphytoplankton present in the three incubations was also different. Thalassiosira spp. dominated in January and February (90\% and $70 \%$ of total microphytoplankton, respectively, Supplementary figure S3) and Lauderia annulata dominated in March (mean 59\% of microphytoplankton cells larger than $5 \mu \mathrm{m}$ ). In January and February, other groups such as Asterionellopsis spp. (4\% and 10\%, respectively) or Cylindrotheca spp. (2\% and 9\%, respectively) were also present, while Guinardia spp. or Chaetoceros spp. were present at relatively low abundance in March (9\% and 1\%). Dinoflagellates were only present during the experiment of March (22\%, Supplementary figure S3). 
The abundance of microphytoplankton-associated bacteria was also analyzed by epifluorescence microscopy. Only cells found in the vicinity of the phycosphere were quantified, including bacteria attached to the phytoplanktonic cells or to the exopolymers surrounding them (Supplementary figure S4). Bacterial abundance was analyzed at the initial time and when phytoplankton abundance was maximum during the incubations (132 h, $108 \mathrm{~h}$ and $12 \mathrm{~h}$ in January, February and March, respectively). We found that at the initial time of the experiments, phytoplankton-associated bacteria were only present in March while in January and February, due to the very low phytoplankton abundance at in situ conditions, no cells with associated bacteria were found using the epifluorescence microscope. The abundance of Flavobacteria and Rhodobacteraceae in March (as cells targeted by CFB315 and Ros537 probes) was 490 and 80 cells $\mathrm{mL}^{-1}$, respectively (Figure 2), together representing the $72 \%$ of all particle-associated bacterial counts in that month and confirming their high abundance in this fraction at the single-cell level. The abundance of microphytoplankton-associated bacteria at the ambient temperature treatment increased during the three experiments (Figure 2). This increase was especially noticeable for Flavobacteria, which consistently exceeded the abundance of Rhodobacteraceae at peak microphytoplankton values for the three experiments (1.8-fold higher abundance of Flavobacteria in January and 3.7-fold higher in February and March, Figure 2). Total bacterial abundance also increased in the free-living fraction, particularly in January and February. The abundance of Flavobacteria between the initial and final times in the freeliving fraction was 45 and 15 times higher in January and February, while the abundance in March increased 2-fold. In contrast, in a microphytoplankton-free control where microphytoplanktonic cells were removed by size fractionation, the bacterial abundance was one order of magnitude lower at the end of all the incubations in comparison to the cells incubated with microphytoplankton (Supplementary Figure S5). Such lower abundance in the absence of microphytoplankton was more noticeable for 
Flavobacteria than for Rhodobacteraceae, where abundances were up to 28 and 10 times higher, respectively, in the treatments with phytoplankton in comparison to the micro-phytoplankton-free treatment.

The abundance of total microphytoplankton cells and the bacteria associated to them increased along the experimental gradient from low to warm treatments in the three experiments (ANOVA, p-value $<0.001$, Figure 3). Bacterial abundances were 2-fold higher in the warm treatment in comparison to the cold one in January and March and 6-fold higher in February. Such increases in abundance were particularly noticeable for Flavobacteria in March, when after only 12 hours of incubation 2.2 times more cells were found in the warm treatment as compared with the cold one, while Rhodobacteraceae abundance was 1.6 times higher. On the contrary, we did not observe any warming effect in the free-living fraction for any of the two taxonomic groups during the 2 to 6-day incubations.

Effect of temperature on ${ }^{13} \mathrm{C}$ and ${ }^{15} \mathrm{~N}$ incorporation by microphytoplankton and microphytoplanktonassociated bacteria

We carried out stable isotope probing (SIP) incubations in the experiment of March, when the sampling was coincident with high in situ Chl a concentration (supplementary figure S2A) and the abundance of diatoms and bacteria associated to them was the maximum of the three experiments. We used ${ }^{13} \mathrm{C}$ bicarbonate and ${ }^{15} \mathrm{~N}$-leucine incubations (after 12 hours of the initial time) to measure bulk uptake by elemental-analysis mass spectrometry (EA-MS), and cell-specific uptake by microphytoplankton and bacteria by nanoSIMS. We found a significant ${ }^{13} \mathrm{C}$ enrichment in bulk samples, with an average uptake of $0.86 \pm 0.34$ atom percent excess (APE), while no effect in ${ }^{13} \mathrm{C}$ APE was found for different temperature treatments. In the cell-specific analysis (Figure 4, Supplementary figure S6), we found that the major 
fraction of ${ }^{13} \mathrm{C}$-bicarbonate was preferentially assimilated by microphytoplankton cells, which showed uptake rates significantly different from 0 (Wilcoxon test, p-value $<0.001$, with all 36 microphytoplankton cells analyzed actively incorporating ${ }^{13} \mathrm{C}$-bicarbonate). On the contrary, ${ }^{15} \mathrm{~N}$-leucine was preferentially assimilated by microphytoplankton-associated heterotrophic bacteria, showing significant incorporation rates (Wilcoxon test, p-value $=0.015$, with $89.7 \%$ of 155 bacteria analyzed actively incorporating ${ }^{15} \mathrm{~N}$ leucine). Yet, we also found that ${ }^{13} \mathrm{C}$ incorporation by heterotrophic bacteria during the incubation, presumably transferred from the primary C-fixing organisms (i.e. microphytoplankton), was significant (Wilcoxon test, p-value $<0.001$ ). For the cell-specific ${ }^{13} \mathrm{C}$ and ${ }^{15} \mathrm{~N}$ uptake measurements using nanoSIMS, bacteria were mostly analyzed in the surroundings of Lauderia annulata and Chaetoceros spp. diatoms, since the phycosphere of these species harbored the highest bacterial abundance while in other abundant groups such as dinoflagellates we virtually did not find any associated microbes. Yet, there was not any difference in ${ }^{13} \mathrm{C}$ uptake between bacteria associated with these two different diatom species (Supplementary figure S7). ${ }^{15} \mathrm{~N}$-leucine incorporation in Rhodobacteraceae was one order of magnitude higher than in Flavobacteria (Wilcoxon test, p-value=0.008, Figure 5B). By contrast, both Flavobacteria and Rhodobacteraceae showed almost identical cell-specific ${ }^{13} \mathrm{C}$ assimilation rates $(0.42 \pm 0.30$ and $0.43 \pm$ $0.15 \mathrm{fg} \mu \mathrm{m}^{-3} \mathrm{~h}^{-1}$, respectively, Figure 5A).

We did not observe any clear effect of warming on microphytoplankton cell-specific ${ }^{13} \mathrm{C}$ incorporation (Supplementary Figure S8). However, we found that ${ }^{13} \mathrm{C}$ assimilation was significantly higher in the warm treatment for both bacterial groups (Wilcoxon test, p-value $<0.001$, Figure $5 \mathrm{~A}$ ), while no differences in ${ }^{15} \mathrm{~N}$ incorporation were found between the distinct temperature treatments for any group (Figure 5B). Due to the low abundance of Rhodobacteraceae in the cold treatment (below 200 cells $\mathrm{mL}^{-1}$ ) and the 
associated difficulty to detect individual cells for the nanoSIMS analysis, for this treatment, we only show assimilation rates for Flavobacteria in Figure 5.

Finally, we also calculated the contribution of each bacterial taxon to total $\mathrm{C}$ and $\mathrm{N}$ assimilation (Figure 5C, D). We found that ${ }^{13} \mathrm{C}$ total assimilation by Flavobacteria was 4 -fold higher than Rhodobacteraceae at ambient temperature, while warming increased this difference up to 6-fold. Assimilation of ${ }^{15} \mathrm{~N}$-leucine by Rhodobacteraceae was 5 times higher than Flavobacteria at ambient temperature $\left(0.64 \pm 0.16 \mathrm{fg} \mathrm{mL}^{-1} \mathrm{~h}^{-1}\right.$ and $0.11 \pm 0.004 \mathrm{fg} \mathrm{mL}^{-1} \mathrm{~h}^{-1}$ respectively), but due to the higher cell abundance of Flavobacteria in the warm treatment, no significant differences in total ${ }^{15} \mathrm{~N}$-leucine assimilation were found between the two groups. 


\section{Discussion}

Marine Flavobacteria and Rhodobacteraceae are two of the most abundant and ecologically relevant bacterial groups in coastal waters (Kirchman, 2002; Buchan et al., 2005), with a well-known opportunistic behavior during phytoplankton blooms (Riemann et al., 2000; Tada et al., 2011; Teeling et al., 2012; Buchan et al., 2014). Previous works have also shown that both bacterial taxa are major components of phytoplankton-associated communities (Grossart et al., 2005; Rooney-Varga et al., 2005) in agreement with our findings at the site of study, where they consistently exceeded the abundance of other typical model copiotrophs such as Alteromonadales. The higher, or at least faster response of Flavobacteria to microphytoplankton growth compared with Rhodobacteraceae also agrees with previous works showing differential responses of various taxonomic groups to increasing microphytoplankton biomass (Tada et al., 2011), and suggests that Flavobacteria may have some ecological advantage over Rhodobacteraceae when competing for newly released DOC.

Moreover, although the initial abundances of both groups in the free-living fraction were similar, when analysing bacteria colonizing microphytoplankton senescent cells (Supplementary figure S9), we observed that Flavobacteria represented on average $80 \%$ of the microphytoplankton-associated bacteria, while Rhodobacteraceae contributed only 13\%. Members of Flavobacteria have shown a high specialization in the degradation of polymeric compounds (Bauer et al., 2006; Gomez-Pereira et al., 2012) and a well described gliding motility, which may be key when colonizing microphytoplankton cells (Kiorboe et al., 2002). The fact that OTUs affiliated to both groups were simultaneously found in the freeliving and particle-associated fractions (Supplementary Figure S10) highlights this colonization ability, indicating that some free-living cells were able to switch between both lifestyles, a process already described to be important in the bacterial dispersion process in the deep sea (Mestre et al., 2018). 
The main aim of our study was to analyse the impact of temperature on the uptake activity of these two copiotrophic taxa thriving in the phycosphere. According to the predictions of the latest IPCC report, climate change may result in surface ocean temperatures $1-3^{\circ} \mathrm{C}$ warmer by the end of this century (IPCC, Pörtner et al., in press). Thus, to test the temperature sensitivity of Flavobacteria and Rhodobacteraceae over a realistic range in this scenario, we used $3^{\circ} \mathrm{C}$ above ambient temperature as the warm treatment. Additionally, we also included a colder treatment $\left(3^{\circ} \mathrm{C}\right.$ below ambient temperature) in order to have a range as broad as possible without putting the communities into thermal stress (Huete-Stauffer et al., 2016; Arandia-Gorostidi et al., 2017a). Since short incubation experiments do not consider potential longterm effects such as bacterial acclimation in response to slow environmental change, caution should be taken when interpreting results obtained from this type of experiments. We deem our results as a way to test the temperature sensitivity of current microbial communities (Kirchman et al., 2005; Huete-Stauffer et al., 2015) and generate plausible hypotheses about the directions of change, which in some cases are confirmed by time-series records (e.g. see Morán et al. 2015 about the shrinkage of bacterial cell size with warming).

In the short-term incubations carried out in this study, we found that experimental warming noticeably increased the abundance of microphytoplankton-associated bacteria, while the effect on the free-living community was less pronounced. Such larger effect of associated bacteria may be explained by at least two mechanisms: (i) increased chemotaxis ability to newly fixed DOC by the microphytoplanktonassociated bacteria (Smriga et al., 2016), which would also promote a faster response to warming as the temperature-sensitivity of bacteria is strongly related to the availability of resources (López-Urrutia and Morán, 2007; Berggren et al., 2010; Moran et al., 2018), and/or (ii) a higher exudation of organic compounds by diatoms at higher temperatures, including transparent exopolymers particle (TEP) (Claquin 
et al., 2008; Wohlers et al., 2009; Seebah et al., 2014), which would facilitate bacterial aggregation (Mari and Kiørboe, 1996; Gardes et al., 2011). In any case, we found that the impact of experimental warming was distinct for the entire associated bacterial community in comparison to the two taxa analysed and that it also exerted a noticeable larger effect on Flavobacteria than on Rhodobacteraceae, indicating a differential response of both taxonomic groups in terms of abundance, as previously observed in freeliving communities (von Scheibner et al., 2014; Arandia-Gorostidi et al., 2017a). Adaptations to detect and exploit DOC hotspots have been well described in both Rhodobacteraceae and Flavobacteria (Miller et al., 2004; Buchan et al., 2005; Fernández-Gómez et al., 2013). Yet, the observed higher response of Flavobacteria to warming suggests that this group may be better adapted to use the newly released DOC within the phycosphere. Interestingly, in a previous study at the same site, we observed that the response to increasing temperature of free-living Rhodobacteraceae was stronger than that of Flavobacteria (Arandia-Gorostidi et al., 2017a), suggesting that the response to warming may differ in each fraction. However, since in the latter study the effect of warming was exclusively tested on the growth rates (not on abundances) of the free-living community, the results of both studies are not fully comparable.

In terms of cell-specific uptake activity, the higher ${ }^{13} \mathrm{C}$ incorporation of microphytoplankton-associated bacteria with increasing temperatures agrees with a previous study (Arandia-Gorostidi et al., 2017b), where only total bacterial communities were analyzed, disregarding potential differences based on taxonomic affiliation. Here, we found a similar response in ${ }^{13} \mathrm{C}$ assimilation rates for the two taxa targeted, Flavobacteria and Rhodobacteraceae, indicating a comparable ability to incorporate algalderived DOC per cell volume, in contrast to the differences in absolute cell abundance found for both groups. These results indicate an imbalance between growth rates and uptake activity for each phylogenetic group. This difference could be explained by (i) a higher growth efficiency of some specific 
clades within Flavobacteria, which with a similar DOC incorporation were able to generate more bacterial biomass, or (ii) a better adaptation of Flavobacteria at detecting new DOC hotspots. Regardless of the underlying mechanism, here we show that due to their higher abundance in the microphytoplanktonassociated fraction, Flavobacteria were quantitatively the major consumers of algal-derived DOC and that this role was significantly enhanced by warming.

We cannot rule out that part of the bacterial incorporation of ${ }^{13} \mathrm{C}$ could be due to anaplerotic assimilation of $\mathrm{CO}_{2}$ (Roslev et al., 2004; Hesselsoe et al., 2005; Alonso-Sáez et al., 2010). However, such incorporation generally represents a minor fraction of total biomass production (between 1 and 6.5\%, Roslev et al., 2004; Hesselsoe et al., 2005). Examples of exceptionally high anaplerotic C assimilation have been demonstrated for some gammaproteobacterial taxa under starvation conditions (Alonso-Sáez et al., 2010), but it is unlikely that microphytoplankton-associated bacteria experience carbon starvation. Furthermore, the $\mathrm{C}$ uptake rates observed in this work are of the same order of magnitude of those reported by earlier studies analyzing algal-derived DOC incorporation by heterotrophic bacteria (Adam et al., 2016; Arandia-Gorostidi et al., 2017b). The fact that bacterial abundance was consistently higher in the presence of microphytoplankton (as compared to microphytoplankton-free controls), also supports the view that most of the ${ }^{13} \mathrm{C}$ assimilation originated from algal-derived DOC.

In the case of microphytoplankton, the lack of effect of temperature on bulk (measured by EA-MS) and cell-specific ${ }^{13} \mathrm{C}$-bicarbonate incorporation was reflected in the low impact of warming on microphytoplankton abundance. We cannot rule out that factors not tested in this work such as nutrient availability or differences in the physiological state of the cells may impact this result. However, our results are consistent with a previous study where picophytoplankton dominated the algal communities at 
the same coastal site (Arandia-Gorostidi et al., 2017b) and other studies showing a lack of increase in particulate primary production with warming (Huete-Stauffer et al., 2017). On the contrary, warming has been related with a relative increase in the release of newly fixed $\mathrm{C}$ as dissolved compounds (Morán et al., 2006; Engel et al., 2011; Yvon-Durocher et al., 2012; Huete-Stauffer et al., 2017), which may explain the clear effects of temperature on the $\mathrm{C}$ uptake activity of microphytoplankton-associated bacteria. Altogether, warming may result in important imbalances of the carbon budget in coastal waters, ultimately transferring more carbon to heterotrophic bacteria in relation to autotrophic cells.

In terms of ${ }^{15} \mathrm{~N}$-Leucine assimilation, the high contribution of Rhodobacteraceae agrees with the high amino-acid uptake activity observed for this group in the free-living fraction as compared to Flavobacteriaceae in marine samples (Alonso and Pernthaler, 2006; Alonso-Sáez and Gasol, 2007; Mayali et al., 2014). Contrary to ${ }^{13} \mathrm{C}$ incorporation, cell-specific ${ }^{15} \mathrm{~N}$-leucine assimilation rates were not enhanced by warming. However, ${ }^{15} \mathrm{~N}$ assimilation rates could indeed have been underestimated because other $\mathrm{N}$ pools such as ammonium, which represents an important $\mathrm{N}$ source for heterotrophic bacteria (Fouilland et al., 2007), were not targeted. Besides, the low activity in leucine uptake by Flavobacteria may have hinder the impact of warming on the amino acid uptake by an important fraction of the microphytoplankton-associated bacterial community. Despite these limitations, the larger temperature effect observed in $\mathrm{C}$ relative to $\mathrm{N}$ uptake may indicate a differential impact of warming to the incorporation of distinct DOM sources, which would have important implications for element cycling in the ocean under warmer conditions.

In a previous work at the same site, a significant effect of warming on the exchange of $\mathrm{C}$ and $\mathrm{N}$ between picophytoplanktonic eukaryotes and attached heterotrophic bacteria was found (Arandia-Gorostidi et al., 
2017b). While picophytoplankton-heterotrophic bacteria interactions can be relevant particularly in the oligotrophic ocean (Agawin et al., 2000; Jardillier et al., 2010), diatom community have been described as the major annual source of organic C for coastal bacterial communities (Smith et al., 1995; Klindworth et al., 2014). In support of this idea, the bacterial C uptake rates reported here under high diatom abundance conditions were 2 to 3 times higher than in the earlier study, when phytoplankton was dominated by small eukaryotes (Arandia-Gorostidi et al., 2017b), even if the ambient temperature was virtually the same (ca. $12^{\circ} \mathrm{C}$ ). Although the difference may be related to the different methods used to calculate the assimilation rates, such results were consistent when we re-calculated the assimilation rates using the equations proposed by Popa et al. (2007), since in Arandia-Gorostidi et al. (2017b) we did not consider isotope correction. However, despite both studies were performed at the same site and under similar environmental conditions, algal-derived DOC uptake and its temperature dependence may also depend of factors no tested in any of both studies, such as inorganic nutrient availability. Thus, additional studies are required to fully understand the consequences of changes in autotrophic community composition on the $\mathrm{C}$ assimilation by their associated bacteria.

In summary, our results show that warming enhanced the use of algal-derived DOC by diatom-associated bacteria. We found that under experimental conditions, the abundance of two copiotrophic bacterial taxa showed a strong increase in response to temperature when associated with microphytoplankton cells, but not in the free-living fraction, while paradoxically most studies on microphytoplankton-bacteria interactions have traditionally focused on the free-living counterparts. Flavobacteria consistently overtook Rhodobacteraceae in terms of biomass production and algal-derived DOC consumption, indicating a dominant role of the former group as DOC-consumers, favored under warm conditions. However, some experimental limitations need to be considered, such as the difference of microphytoplankton abundance 
and their physiological state between the experiments, which may have an impact in the DOC pool available for bacteria and, hence, in their response to temperature (López-Urrutia and Morán, 2007). The difference in incubation time (due to the differences in the growth of microphytoplankton in the three experiments) may have also resulted in a longer acclimation period in the first two experiments, which may ultimately influence the future bacterial response to warming. Yet, we found that in the three experiments, the response of microbial abundance to temperature was consistent, indicating that regardless of in situ conditions, temperature may have an important impact on the abundance of microphytoplankton-associated bacteria. Although many uncertainties about the impact of climate change on the microphytoplankton-bacteria coupling remain, our work represents a step forward towards elucidating the interactions taking place in the complex environment of the phycosphere. Latest technological advancements such as nanoSIMS have allowed the precise determination of $\mathrm{C}$ and $\mathrm{N}$ incorporation within this niche, which may impact not only the individual cells but also the global cycling of these elements at ecosystem level (Seymour et al., 2017). Here, we demonstrated that experimental changes in temperature impacted the composition of the microphytoplankton-associated bacteria and the DOM cycling within the phycosphere, which highlights the importance of this microenvironment to study the future consequences of global change for ocean carbon cycling. 


\section{Experimental procedures}

\section{DNA samples collection and processing}

During a 3-year in situ analysis (December 2009-December 2012) surface seawater was collected monthly at the coastal station E2 $\left(43.675^{\circ} \mathrm{N}, 5.578^{\circ} \mathrm{W}\right)$ located $13 \mathrm{~km}$ off Gijón/Xixón (Spain) in the southern Bay of Biscay. Five-liter Niskin bottles were filled with seawater and transported to the lab in the dark within the next 6 hours. Seawater was sequentially filtered through $3 \mu \mathrm{m}$ pore-size polycarbonate filters (GTTP, 25mm, Millipore, Eschborn, Germany), to retain bacteria associated to particles and microphytoplankton cells, and through $0.2 \mu \mathrm{m}$ pore size filters to collect the free-living fraction (AlonsoSáez et al., 2015). Filters were stored at $-80^{\circ} \mathrm{C}$ before DNA extraction. Other parameters such as

temperature, chlorophyll $a$ and nitrate concentration were measured in the lab. Chlorophyll $a$ concentration was determined by filtering $200 \mathrm{~mL}$ of seawater on $0.22 \mu \mathrm{m}$ pore-size polycarbonate filters. Filters were frozen at $-20^{\circ} \mathrm{C}$ and processed within 2 weeks as described in Calvo-Díaz and Morán (2006). Samples for nitrate concentration were determined with a Technicon autoanalyzer as indicated in CalvoDíaz and Morán (2006).

From monthly samples collected along a 3-year period, a total of 11 samples corresponding to months with different concentrations of chlorophyll $a$ were selected for DNA sequencing of both the microphytoplankton-associated and free-living fractions. DNA extraction and 16S rDNA genes amplification were carried out following Alonso-Sáez et al. (2015) using general bacterial primers 341F and 805R (Herlemann et al., 2011). Triplicate PCR products were purified using a QIAquick purification Kit (Qiagen, Hilden, Germany) and amplicons were sequenced using a 454 FLX+ platform (Lifesequencing). Sequences were analyzed using the MOTHUR platform (Schloss et al., 2009) as 
described in Alonso-Sáez et al. (2015). Samples were rarefied to 2535 sequences per sample, obtaining a total of 55770 sequences for analysis. Sequences have been deposited in the European Nucleotide Archive project PRJEB6399 (accession numbers ERS1836182- ERS1836193 for the microphytoplankton-associated sequences deposited from this study).

\section{Temperature-controlled experiments setup}

Seawater was collected at the E2 station in January $26^{\text {th }}$, February $19^{\text {th }}$ and March $22^{\text {nd }}$ in 2014 . The collected water was pre-filtered by $200 \mu \mathrm{m}$ pore size filters to remove mesozooplankton and transported to the laboratory in 20 L Nalgene polycarbonate bottles (Nalgene, Rochester, NY, USA) within 6 hours from collection. At the arrival in the laboratory, seawater was distributed into polycarbonate bottles for incubation experiments (2 L per bottle). Additionally, we prepared a control with $2 \mathrm{~L}$ of seawater filtered by $0.8 \mu \mathrm{m}$ pore size cartridge filters (Pall, Ilfracombe, United Kingdom) in order to remove microphytoplankton cells. This treatment is referred as microphytoplankton-free treatment. We incubated the water samples at 3 different temperatures: i) ambient temperature $\left(12.5-13^{\circ} \mathrm{C}\right)$, ii) $3^{\circ} \mathrm{C}$ below $(9.5-10$ ${ }^{\circ} \mathrm{C}$, cold treatment) and iii) $3^{\circ} \mathrm{C}$ above ambient temperature $\left(15.5-16^{\circ} \mathrm{C}\right.$, warm treatment). Two duplicate bottles were incubated at each temperature and the additional microphytoplankton-free treatment bottle at ambient temperature. The temperature-controlled incubations were carried out at the natural photoperiod of each month, under saturating PAR irradiance (ca. $150 \mu \mathrm{mol}$ photons $\mathrm{m}^{-2} \mathrm{~s}^{-1}$ ) and lasted up to 7 days.

Each day, $25 \mathrm{~mL}$ were removed from the bottles and fixed with $2 \%$ of Lugol solution for microphytoplankton taxonomy analysis (identifying cells with a diameter larger than $5 \mu \mathrm{m}$ ). Microphytoplankton cells were identified up to genus or species level in most of the cases, using an inverted microscope (Lund et al., 1958) with a final magnification of x20. To determine total 
microphytoplankton abundance, a minimum of 300 cells were count when possible, with an error of $11.5 \%$ for a $95 \%$ CI. When microphytoplankton abundance was very low (as at in situ conditions of January and February) a minimum of 100 cells were count (20\% error).

At the initial time of the incubations and when microphytoplankton abundance reached maximum abundance, we filtered additional volumes onto $0.2 \mu \mathrm{m}$ pore-size filters $(5 \mathrm{~mL})$ and $3 \mu \mathrm{m}$ pore-size filters (100 mL) to quantify the abundance of Rhodobacteraceae and Flavobacteria in the microphytoplanktonassociated and free-living fractions by Catalyzed Reporter Deposition Fluorescence In situ Hybridization (CARD-FISH). CARD-FISH analysis was performed following Pernthaler et al. (2002). Hybridizations were carried out using $9 \mu \mathrm{L}$ the Horseradish peroxidase (HRP) labeled probes (50 ng $\mu \mathrm{L}^{-1}$ ) Ros537 and CF319 (Manz et al., 1996; Eilers et al., 2001) diluted in $900 \mu \mathrm{L}$ of hybridization buffer with 55\% formamide. Fluorescently-labeled tyramide Alexa Fluor ${ }^{\circledR} 488\left(1 \mathrm{mg} \mathrm{mL}^{-1}, 46^{\circ} \mathrm{C}, 30 \mathrm{~min}\right.$, ThermoFisher, Germany) was used for the amplification step. The hybridized cells were further stained with 4',6diamidino-2-phenylindole (DAPI) at $1 \mu \mathrm{g} \mathrm{mL} \mathrm{m}^{-1}$ and were quantified using an epifluorescence microscope Leica DM5500B. In order to provide absolute cell-abundance counts, cell abundance of Flavobacteria and Rhodobacteraceae was calculated based on the number of probe-specific hybridized cells per mL of filtered seawater, while abundance of the total bacterial community was based on the total DAPI counts. Counts of hybridized bacteria were calculated from 10 randomly chosen microscopic fields. A minimum of 200 DAPI stained cells were counted in the microphytoplankton-associated fraction and 1000 cells in the free-living fraction in order to have a representative estimation of total bacterial abundance.

In order to obtain updated values of coverage of the CF319 and Ros537 probes used in this study, we used the TestProbe 3.0 tool against the SILVA database. According to this analysis, the Ros537 probe almost exclusively targets the Rhodobacterales order (63\% of known $16 \mathrm{~S}$ sequences of this group). At the 
family level, Ros537 exclusively targets Rhodobacteraceae family (which is the only marine representative of the Rhodobacterales order identified in our 16S data-set, with 63\% coverage), including different genera such as Roseobacter (with 95\% of coverage), Sulfitobacter (81\% coverage), Planktomarina (98\% coverage) or Donghicola (90\% coverage). Yet, the main OTUs found in our study site were only affiliated to the Roseobacter and Donghicola genera (Supplementary figure S10). The probe CF319a targets mostly the Bacteroidia class (48\% coverage), and two marine Flavobacteria orders: Flavobacteriales (89\% coverage) and Sphingobacteriales (88\% coverage). Although both orders have been detected at our study site, Flavobacteriales was considerably more abundant (22.3\% in average) than Sphingobacteriales (6.1\%).

Stable isotope probing and nanoSIMS analysis

For quantifying cell-specific $\mathrm{C}$ and $\mathrm{N}$ uptake for both microphytoplankton associated and free-living bacterial groups, water samples were collected in March $\left(22^{\text {nd }}, 2014\right)$ when the highest chlorophyll values were recorded. The freshly collected water samples were incubated for 12 hours at different temperatures (see temperature-controlled experiment above) followed by subsampling of $250 \mathrm{~mL}$ from each replicate of the different temperature treatments $\left(+3^{\circ} \mathrm{C}\right.$, ambient temperature and $\left.-3^{\circ} \mathrm{C}\right)$ to duplicate Pyrex glass bottles for the stable isotope probing (SIP) incubations. To this volume, we added $300 \mu \mathrm{mol} \mathrm{L}{ }^{-1}$ of ${ }^{13} \mathrm{C}$ bicarbonate (99 atom $\%{ }^{13} \mathrm{C}$, Cambridge Isotope Laboratories Inc., Cambridge, MA, USA), equivalent to $15 \%{ }^{13} \mathrm{C}$ after dilution with ambient $\mathrm{HCO}_{3}{ }^{-}$, and $50 \mathrm{nmol} \mathrm{L}^{-1}$ of ${ }^{15} \mathrm{~N}$-leucine (Cambridge Isotopes). The SIP incubations lasted for $12 \mathrm{~h}$ at each of the corresponding temperatures.

For the nanoSIMS analysis, $100 \mathrm{~mL}$ from each replicate and each temperature treatment was fixed at the end of the SIP incubation with $4 \%$ formaldehyde for 3 hours at room temperature and filtered through 
gold-palladium coated polycarbonate filters (type GTTP; pore size, $3 \mu \mathrm{m}$; diameter, $47 \mathrm{~mm}$; Millipore, Eschborn, Germany). Filters were stored at $-80^{\circ} \mathrm{C}$ until analysis. First, filters were hybridized using the HRP-labeled nucleotide probes as described above. The amplification step was done using either fluorine containing fluorescently labeled tyramides Oregon Green ${ }^{\circledR} 488$ (ThermoFisher, Germany) or the Alexa Fluor ${ }^{\circledR} 488$ (ThermoFisher, Germany) following the protocol by Musat et al. (2008). Hybridized cells were identified and mapped by using a laser microdissection system (LMD, Zeiss, Germany) equipped with an inverted epifluorescence microscope. Several areas containing target cells were mapped in the LMD system using an air-objective with 60X magnification as previously described by Alonso et al. (2012).

The LMD marked areas were further analyzed with a nanoSIMS 50L (Cameca, Gennevilliers, France) extracting negative secondary ions upon sample sputtering with primary Cs+ ions. The 2 pA beam of $16 \mathrm{keV} \mathrm{Cs}{ }^{+}$ions was focused into about $70 \mathrm{~nm}$ spot at the sample surface during the analysis. Samples were analyzed in a $512 \times 512$ px raster over $30 \times 30 \mu \mathrm{m}^{2}$ areas with $5 \mathrm{msec}$ dwell time per pixel. Before the analysis, the sample surface was treated with $10 \mathrm{nA}$ of low-energy $(50 \mathrm{eV}) \mathrm{Cs}^{+}$beam over $80 \times 80 \mu \mathrm{m}^{2}$ area for 10 minutes. The secondary ions species were analyzed for their mass to charge ratio (m/z) and detected using the seven available collectors: ${ }^{12} \mathrm{C}^{-},{ }^{13} \mathrm{C}^{-},{ }^{19} \mathrm{~F}^{-},{ }^{12} \mathrm{C}^{14} \mathrm{~N}^{-},{ }^{12} \mathrm{C}^{15} \mathrm{~N}^{-}$and ${ }^{13} \mathrm{C}^{14} \mathrm{~N}^{-},{ }^{31} \mathrm{P}^{-}$, ${ }^{32} \mathrm{~S}^{-}$. Two secondary ion species $\left({ }^{12} \mathrm{C}^{15} \mathrm{~N}^{-}\right.$and $\left.{ }^{13} \mathrm{C}^{14} \mathrm{~N}^{-}\right)$were detected by switching the deflector voltage in combined analysis mode. The mass resolving power (MRP) was checked to be between 7000 and 10000 with the exit slit width of $70 \mu \mathrm{m}, 20 \mu \mathrm{m}$ entrance slit width, $200 \mu \mathrm{m}$ aperture slit and with the energy slit cutting about $30 \%$ of secondary ions in high-energy tail of their energy distribution. Under these analysis conditions, we observed that cells got sputtered completely within 10 scans. Scans 3-8 were considered for the analysis employing LANS software (Polerecky et al., 2012) allowing for the accumulation of the 
scans with lateral drift correction and quantitative analysis of isotopic ratios $\left({ }^{13} \mathrm{C} /{ }^{12} \mathrm{C},{ }^{13} \mathrm{C}^{14} \mathrm{~N} /{ }^{12} \mathrm{C}^{14} \mathrm{~N}\right.$ and ${ }^{12} \mathrm{C}^{15} \mathrm{~N} /{ }^{12} \mathrm{C}^{14} \mathrm{~N}$ ). Identification of bacterial cells in the nanoSIMS images was performed by using ${ }^{12} \mathrm{C}^{14} \mathrm{~N}$ and ${ }^{31} \mathrm{P}^{-}$channels, which allowed to differentiate the cells from the background signal, while identification of hybridized cells was done by comparison with the epifluorescence images. To determine cell-specific isotope ratios, regions of interest (ROIs) were drawn inside the cells, avoiding the cell-surrounding areas. To quantify the natural abundances of ${ }^{13} \mathrm{C}^{14} \mathrm{~N} /{ }^{12} \mathrm{C}^{14} \mathrm{~N}$ and ${ }^{12} \mathrm{C}^{15} \mathrm{~N} /{ }^{12} \mathrm{C}^{14} \mathrm{~N}$ in our samples, we analyzed the isotopic ratios on non-labeled samples collected just before the SIP incubation of March. Changes in the isotope composition during stable isotope labeling measured by nanoSIMS were generally considered quantitatively to calculate assimilation rates of single cells, following the calculations provided in Stryhanyuk et al. (2018). Assimilation rates were calculated as the fraction $\left(K_{A}\right)$ of carbon or nitrogen assimilated into a cell during its incubation in isotope-labeled growth substrate:

$$
K_{A}=\frac{R_{f}-R_{i}}{R_{i}+1} \times \frac{R_{g s}+1}{R_{g s}-R_{f}}
$$

Where $R_{g s}$ is the isotope ratio of the growth substrate during incubation, $R_{i}$ is the initial isotope ratio before incubation, and $R_{f}$ is the isotope ratio after incubation. With the isotope ratios $(R)$ defined as heavy-to-light ratio for carbon isotopes, $R={ }^{13} \mathrm{C} /{ }^{12} \mathrm{C}$, the fractions of heavy and light isotopes ( $D_{\text {heavy }}$ and $D_{\text {light }}$ ) were expressed as follows:

$$
D_{\text {heavy }} \equiv D=\frac{{ }^{13} C}{{ }^{13} C+{ }^{12} C}=\frac{R}{R+1} \text { and } D_{\text {light }}=\frac{{ }^{12} C}{{ }^{13} C+{ }^{12} C}=\frac{1}{R+1} \text {. }
$$

For performing the calculations, we considered a value of $64.6 \%$ of $\mathrm{C}$ dilution due to the CARD-FISH treatment (Musat et al., 2014). In the case of nitrogen, since $\mathrm{N}$ loss during the treatment could not be 
modeled, we decided to omit any $\mathrm{N}$ correction. Besides isotope correction, we also considered the following parameters during the calculations: the fraction of the isotopes in chemicals used for the treatment and the isotope ratio after the CARD-FISH. Cell biovolume (in $\mu^{3}$ ) was estimated from the bacterial diameter measured from the nanoSIMS images and assuming a spherical form. The partial density of carbon and nitrogen for bacteria $\left(111.9 \pm 45.5 \mathrm{fg} \mathrm{C} \mathrm{mm}^{-3}\right.$ and $21.5 \pm 5.6 \mathrm{fg} \mathrm{N} \mathrm{mm}^{-3}$, Fukuda et al., 1998) and for microphytoplankton (140.0 fg C $\mu \mathrm{m}^{-3}$ and $10.0 \mathrm{fg} \mathrm{N} \mu \mathrm{m}^{-3}$, Putt and Stoecker, 1989; Montagnes and Franklin, 2001) were used to obtain the final $\mathrm{C}$ and $\mathrm{N}$ assimilation rates per unit $\left(\mu \mathrm{m}^{3}\right)$ of cell volume. We also calculated $\mathrm{C}$ and $\mathrm{N}$ assimilation rates per cell (Supplementary Table S1). In addition, $\mathrm{C}$ and $\mathrm{N}$ assimilation rates were also determined according to the calculations described by Popa et al. (2007), without considering any isotope correction, in order to compare our results with ones obtained in Arandia-Gorostidi et al. (2017b) (Supplementary Table S2).

To determine the assimilation of carbon and nitrogen by Flavobacteria and Rhodobacteraceae cells, we calculated total $\mathrm{C}$ and $\mathrm{N}$ uptake in $\mathrm{fg} \mathrm{mL}^{-1}$ by multiplying the assimilation rate per volume by the total biovolume of each taxonomic group.

\section{Analysis of bulk C assimilation by an elemental analyser}

In addition to cell-specific analysis, at the end of the SIP incubation, $50 \mathrm{~mL}$ of each bottle were filtered through pre-combusted $\mathrm{GF} / \mathrm{F}$ filters and stored at $-80^{\circ} \mathrm{C}$ to determine ${ }^{13} \mathrm{C} /{ }^{12} \mathrm{C}$ isotope ratio by an

elemental-analysis mass spectrometry (EA-MS). Several round slices of each GF/F filters (with a diameter of $0.5 \mathrm{~cm}$ ) were packed in small cups and dried overnight at $55^{\circ} \mathrm{C}$. Dried filter packages were loaded onto an autosampler and assimilation of bulk C was analysed by a Euro EA3000 elemental analyzer (HEKAtech, Germany) equipped with a commercially available combustion reactor filled with 
tungsten oxide and silver cobalt oxide (HE46820995, HEKAtech, Germany) and connected to a gas analyser (GAM 445, Balzers AG, Balzers, Liechtenstein) using caffeine as standard for isotope correction. Bulk C assimilation was determined as atom percent enrichment (APE) over the natural abundance, as described in the following equation:

$$
A P E=\left(D_{f}-D_{i}\right) * 100
$$

Where $\mathrm{D}_{\mathrm{f} / \mathrm{i}}$ is the fraction of ${ }^{13} \mathrm{C}$ at the final and initial sampling time, respectively

$$
D_{f / i}=\frac{{ }^{13} \mathrm{C}}{{ }^{12} \mathrm{C}+{ }^{13} \mathrm{C}}
$$


Conflict of interest: The authors declare that they have no conflict of interest.

Acknowledgments. We are grateful to Basque Government for supporting N.A.G.'s Ph.D. fellowship the Spanish Ministry of Economy and Competitiveness (MINECO) for supporting L.A.S.'s Juan de la Cierva and Ramón y Cajal (RYC-2012-11404) fellowships and the COMITE project (CTM-2010-15840). We thank the Helmholtz Centre for Environmental Research and the Department of Isotope Biogeochemistry for providing the access to their infrastructure (ProVIS) and to M. G. for the EA-MS analysis. We are very thankful to all the staff of the R/V “José de Rioja” for their help during the sampling collection and L. Díaz and T.M. Huete-Stauffer for their help during the experiments. 


\section{References}

Adam, B., Klawonn, I., Sveden, J.B., Bergkvist, J., Nahar, N., Walve, J. et al. (2016) N2-fixation, ammonium release and $\mathrm{N}$-transfer to the microbial and classical food web within a plankton community. ISME J 10: 450-459.

Agawin, N.S.R., Duarte, C.M., and Agustí, S. (2000) Nutrient and temperature control of the contribution of picoplankton to phytoplankton biomass and production. Limnology and Oceanography 45: 1891-1891.

Alonso-Sáez, L., and Gasol, J.M. (2007) Seasonal variations in the contributions of different bacterial groups to the uptake of low-molecular-weight compounds in northwestern Mediterranean coastal waters. Appl Environ Microbiol 73: 3528-3535.

Alonso-Sáez, L., Díaz-Pérez, L., and Morán, X.A.G. (2015) The hidden seasonality of the rare biosphere in coastal marine bacterioplankton. Environ Microbiol 17: 3766-3780.

Alonso-Sáez, L., Galand, P.E., Casamayor, E.O., Pedros-Alio, C., and Bertilsson, S. (2010) High bicarbonate assimilation in the dark by Arctic bacteria. ISME J 4: 1581-1590.

Alonso, C., and Pernthaler, J. (2006) Concentration-dependent patterns of leucine incorporation by coastal picoplankton. Appl Environ Microbiol 72: 2141-2147.

Alonso, C., Musat, N., Adam, B., Kuypers, M., and Amann, R. (2012) HISH-SIMS analysis of bacterial uptake of algal-derived carbon in the Rio de la Plata estuary. Syst Appl Microbiol 35: 541-548.

Arandia-Gorostidi, N., Huete-Stauffer, T.M., Alonso-Sáez, L., and Morán, X.A.G. (2017a) Testing the metabolic theory of ecology with marine bacteria: different temperature sensitivity of major phylogenetic groups during the spring phytoplankton bloom. Environ Microbiol.

Arandia-Gorostidi, N., Weber, P.K., Alonso-Sáez, L., Morán, X.A.G., and Mayali, X. (2017b) Elevated temperature increases carbon and nitrogen fluxes between phytoplankton and heterotrophic bacteria through physical attachment. ISME J 11: 641-650.

Azam, F. (1998) OCEANOGRAPHY: Microbial Control of Oceanic Carbon Flux: The Plot Thickens. Science 280: 694-696.

Bauer, M., Kube, M., Teeling, H., Richter, M., Lombardot, T., Allers, E. et al. (2006) Whole genome analysis of the marine Bacteroidetes'Gramella forsetii' reveals adaptations to degradation of polymeric organic matter. Environ Microbiol 8: 2201-2213. 
Behrenfeld, M.J., Randerson, J.T., McClain, C.R., Feldman, G.C., Los, S.O., Tucker, C.J. et al. (2001)

Biospheric primary production during an ENSO transition. Science 291: 2594-2597.

Bell, W., and Mitchell, R. (1972) Chemotactic and Growth Responses of Marine Bacteria to Algal Extracellular Products. The Biological Bulletin 143: 265-277.

Berggren, M., Laudon, H., Jonsson, A., and Jansson, M. (2010) Nutrient constraints on metabolism affect the temperature regulation of aquatic bacterial growth efficiency. Microb Ecol 60: 894-902.

Buchan, A., González, J.M., and Moran, M.A. (2005) Overview of the marine roseobacter lineage. Appl Environ Microbiol 71: 5665-5677.

Buchan, A., LeCleir, G.R., Gulvik, C.A., and Gonzalez, J.M. (2014) Master recyclers: features and functions of bacteria associated with phytoplankton blooms. Nat Rev Microbiol 12: 686-698.

Caffrey, J.M., Cloern, J.E., and Grenz, C. (1998) Changes in production and respiration during a spring phytoplankton bloom in San Francisco Bay, California, USA:implications for net ecosystem metabolism. Marine Ecology Progress Series 172: 1-12.

Calvo-Díaz, A., and Morán, X.A.G. (2006) Seasonal dynamics of picoplankton in shelf waters of the southern Bay of Biscay. Aquatic Microbial Ecology 42: 159-174.

Chrost, R.H., and Faust, M.A. (1983) Organic carbon release by phytoplankton: its composition and utilization by bacterioplankton. Journal of Plankton Research 5: 477-493.

Claquin, P., Probert, I., Lefebvre, S., and Veron, B. (2008) Effects of temperature on photosynthetic parameters and TEP production in eight species of marine microalgae. Aquatic Microbial Ecology 51: 1-11.

Duarte, C.M., Agustí, S., Vaqué, D., Agawin, N.S.R., Felipe, J., Casamayor, E.O., and Gasol, J.M. (2005) Experimental test of bacteria-phytoplankton coupling in the Southern Ocean. Limnology and Oceanography 50: 1844-1854.

Eilers, H., Pernthaler, J., Peplies, J., Glockner, F.O., Gerdts, G., and Amann, R. (2001) Isolation of novel pelagic bacteria from the German bight and their seasonal contributions to surface picoplankton. Appl Environ Microbiol 67: 5134-5142.

Engel, A., Handel, N., Wohlers, J., Lunau, M., Grossart, H.P., Sommer, U., and Riebesell, U. (2011) Effects of sea surface warming on the production and composition of dissolved organic matter during phytoplankton blooms: results from a mesocosm study. Journal of Plankton Research 33: 357-372. 
Fernández-Gómez, B., Richter, M., Schuler, M., Pinhassi, J., Acinas, S.G., González, J.M., and PedrósAlió, C. (2013) Ecology of marine Bacteroidetes: a comparative genomics approach. ISME J 7: 1026-1037.

Field, C.B. (1998) Primary Production of the Biosphere: Integrating Terrestrial and Oceanic Components. Science 281: 237-240.

Fouilland, E., Gosselin, M., Rivkin, R.B., Vasseur, C., and Mostajir, B. (2007) Nitrogen uptake by heterotrophic bacteria and phytoplankton in Arctic surface waters. Journal of Plankton Research 29: 369-376.

Fukuda, R., Ogawa, H., Nagata, T., and Koike, I.I. (1998) Direct determination of carbon and nitrogen contents of natural bacterial assemblages in marine environments. Appl Environ Microbiol 64: 3352-3358.

Gardes, A., Iversen, M.H., Grossart, H.P., Passow, U., and Ullrich, M.S. (2011) Diatom-associated bacteria are required for aggregation of Thalassiosira weissflogii. ISME J 5: 436-445.

Gómez-Pereira, P.R., Fuchs, B.M., Alonso, C., Oliver, M.J., van Beusekom, J.E., and Amann, R. (2010) Distinct flavobacterial communities in contrasting water masses of the north Atlantic Ocean. ISME J 4: 472-487.

Gómez-Pereira, P.R., Schuler, M., Fuchs, B.M., Bennke, C., Teeling, H., Waldmann, J. et al. (2012) Genomic content of uncultured Bacteroidetes from contrasting oceanic provinces in the North Atlantic Ocean. Environ Microbiol 14: 52-66.

Grossart, H.P., Tang, K.W., Kiorboe, T., and Ploug, H. (2007) Comparison of cell-specific activity between free-living and attached bacteria using isolates and natural assemblages. FEMS Microbiol Lett 266: 194-200.

Grossart, H.P., Levold, F., Allgaier, M., Simon, M., and Brinkhoff, T. (2005) Marine diatom species harbour distinct bacterial communities. Environ Microbiol 7: 860-873.

Herlemann, D.P.R., Labrenz, M., Jurgens, K., Bertilsson, S., Waniek, J.J., and Andersson, A.F. (2011) Transitions in bacterial communities along the $2000 \mathrm{~km}$ salinity gradient of the Baltic Sea. ISME Journal 5: 1571-1579.

Hesselsoe, M., Nielsen, J.L., Roslev, P., and Nielsen, P.H. (2005) Isotope labeling and microautoradiography of active heterotrophic bacteria on the basis of assimilation of $14 \mathrm{CO}(2)$. Appl Environ Microbiol 71: 646-655. 
Hoppe, H.G., Breithaupt, P., Walther, K., Koppe, R., Bleck, S., Sommer, U., and Jürgens, K. (2008) Climate warming in winter affects the coupling between phytoplankton and bacteria during the spring bloom: a mesocosm study. Aquatic Microbial Ecology 51: 105-115.

Huete-Stauffer, T.M., Arandia-Gorostidi, N., Díaz-Pérez, L., and Morán, X.A.G. (2015) Temperature dependences of growth rates and carrying capacities of marine bacteria depart from metabolic theoretical predictions. FEMS Microbiol Ecol 91.

Huete-Stauffer, T.M., Arandia-Gorostidi, N., Alonso-Sáez, L., and Moran, X.A.G. (2016) Experimental Warming Decreases the Average Size and Nucleic Acid Content of Marine Bacterial Communities. Front Microbiol 7: 730.

Huete-Stauffer, T.M., Arandia-Gorostidi, N., González-Benítez, N., Díaz-Pérez, L., Calvo-Díaz, A., and Morán, X.A.G. (2017) Large Plankton Enhance Heterotrophy Under Experimental Warming in a Temperate Coastal Ecosystem. Ecosystems.

Jardillier, L., Zubkov, M.V., Pearman, J., and Scanlan, D.J. (2010) Significant CO2 fixation by small prymnesiophytes in the subtropical and tropical northeast Atlantic Ocean. ISME J 4: 1180-1192.

Jiao, N., Herndl, G.J., Hansell, D.A., Benner, R., Kattner, G., Wilhelm, S.W. et al. (2010) Microbial production of recalcitrant dissolved organic matter: long-term carbon storage in the global ocean. Nat Rev Microbiol 8: 593-599.

Joiris, C., Billen, G., Lancelot, C., Daro, M.H., Mommaerts, J.P., Bertels, A. et al. (1982) A budget of carbon cycling in the Belgian coastal zone: relative roles of zooplankton, bacterioplankton and benthos in the utilization of primary production. Netherlands Journal of Sea Research 16: 260275.

Kiorboe, T., Grossart, H.P., Ploug, H., and Tang, K. (2002) Mechanisms and rates of bacterial colonization of sinking aggregates. Appl Environ Microbiol 68: 3996-4006.

Kirchman, D. (2002) The ecology of Cytophaga-Flavobacteria in aquatic environments. FEMS Microbiology Ecology 39: 91-100.

Kirchman, D.L., Malmstrom, R.R., and Cottrell, M.T. (2005) Control of bacterial growth by temperature and organic matter in the Western Arctic. Deep Sea Research Part II: Topical Studies in Oceanography 52: 3386-3395. 
Klindworth, A., Mann, A.J., Huang, S., Wichels, A., Quast, C., Waldmann, J. et al. (2014) Diversity and activity of marine bacterioplankton during a diatom bloom in the North Sea assessed by total RNA and pyrotag sequencing. Mar Genomics 18 Pt B: 185-192.

López-Urrutia, Á., and Morán, X.A.G. (2007) Resource Limitation of Bacterial Production Distorts the Temperature Dependence of Oceanic Carbon Cycling. Ecology 88: 817-822.

Lund, J.W.G., Kipling, C., and Le Cren, E.D. (1958) The inverted microscope method of estimating algal numbers and the statistical basis of estimations by counting. Hydrobiologia 11: 143-170.

Manz, W., Amann, R., Vancanneyt, M., Schleifer, K.-H., and Ludwig, W. (1996) Application of a suite of 16S rRNA-specific oligonucleotide probes designed to investigate bacteria of the phylum cytophaga-flavobacter-bacteroides in the natural environment. Microbiology 142: 1097-1106.

Mari, X., and Kiørboe, T. (1996) Abundance, size distribution and bacterial colonization of transparent exopolymeric particles (TEP) during spring in the Kattegat. Journal of Plankton Research 18: 969-986.

Mayali, X., Weber, P.K., Mabery, S., and Pett-Ridge, J. (2014) Phylogenetic patterns in the microbial response to resource availability: amino acid incorporation in San Francisco Bay. PLoS One 9: e95842.

Meon, B., and Kirchman, D.L. (2001) Dynamics and molecular composition of dissolved organic material during experimental phytoplankton blooms. Marine Chemistry 75: 185-199.

Mestre, M., Ruiz-González, C., Logares, R., Duarte, C.M., Gasol, J.M., and Sala, M.M. (2018) Sinking particles promote vertical connectivity in the ocean microbiome. Proc Natl Acad Sci U S A 115: E6799-E6807.

Miller, T.R., Hnilicka, K., Dziedzic, A., Desplats, P., and Belas, R. (2004) Chemotaxis of Silicibacter sp. strain TM1040 toward dinoflagellate products. Appl Environ Microbiol 70: 4692-4701.

Montagnes, D.J.S., and Franklin, M. (2001) Effect of temperature on diatom volume, growth rate, and carbon and nitrogen content: Reconsidering some paradigms. Limnology and Oceanography 46: 2008-2018.

Moran, M.A. (2015) The global ocean microbiome. Science 350: aac8455.

Morán, X.A.G., Calvo-Diaz, A., Arandia-Gorostidi, N., and Huete-Stauffer, T.M. (2018) Temperature sensitivities of microbial plankton net growth rates are seasonally coherent and linked to nutrient availability. Environ Microbiol 20: 3798-3810. 
Morán, X.A.G., Sebastián, M., Pedrós-Alió, C., and Estrada, M. (2006) Response of Southern Ocean phytoplankton and bacterioplankton production to short-term experimental warming. Limnology and Oceanography 51: 1791-1800.

Musat, N., Stryhanyuk, H., Bombach, P., Adrian, L., Audinot, J.N., and Richnow, H.H. (2014) The effect of FISH and CARD-FISH on the isotopic composition of (13)C- and (15)N-labeled Pseudomonas putida cells measured by nanoSIMS. Syst Appl Microbiol 37: 267-276.

Musat, N., Halm, H., Winterholler, B., Hoppe, P., Peduzzi, S., Hillion, F. et al. (2008) A single-cell view on the ecophysiology of anaerobic phototrophic bacteria. Proc Natl Acad Sci U S A 105: 1786117866.

Norrman, B., Zweifel, U.L., Hopkinson, C.S., and Fry, B. (1995) Production and Utilization of Dissolved Organic-Carbon during an Experimental Diatom Bloom. Limnology and Oceanography 40: 898907.

Pernthaler, A., Pernthaler, J., and Amann, R. (2002) Fluorescence in situ hybridization and catalyzed reporter deposition for the identification of marine bacteria. Appl Environ Microbiol 68: 30943101.

Pinhassi, J., Sala, M.M., Havskum, H., Peters, F., Guadayol, O., Malits, A., and Marrase, C. (2004) Changes in bacterioplankton composition under different phytoplankton regimens. Appl Environ Microbiol 70: 6753-6766.

Polerecky, L., Adam, B., Milucka, J., Musat, N., Vagner, T., and Kuypers, M.M. (2012) Look@NanoSIMS--a tool for the analysis of nanoSIMS data in environmental microbiology. Environ Microbiol 14: 1009-1023.

Pörtner, H.O., Roberts, D.C., Masson-Delmotte, V., Zhai, P., Poloczanska, E., Mintenbeck, K., et al., In: IPCC Special Report on the Ocean and Cryosphere in a Changing Climate. In press

Putt, M., and Stoecker, D.K. (1989) An experimentally determined carbon : volume ratio for marine “oligotrichous” ciliates from estuarine and coastal waters. Limnology and Oceanography 34: 1097-1103.

Riemann, L., Steward, G.F., and Azam, F. (2000) Dynamics of Bacterial Community Composition and Activity during a Mesocosm Diatom Bloom. Applied and Environmental Microbiology 66: 578587. 
Rooney-Varga, J.N., Giewat, M.W., Savin, M.C., Sood, S., LeGresley, M., and Martin, J.L. (2005) Links between phytoplankton and bacterial community dynamics in a coastal marine environment. Microb Ecol 49: 163-175.

Roslev, P., Larsen, M.B., Jorgensen, D., and Hesselsoe, M. (2004) Use of heterotrophic CO2 assimilation as a measure of metabolic activity in planktonic and sessile bacteria. J Microbiol Methods 59: 381-393.

Schloss, P.D., Westcott, S.L., Ryabin, T., Hall, J.R., Hartmann, M., Hollister, E.B. et al. (2009) Introducing mothur: open-source, platform-independent, community-supported software for describing and comparing microbial communities. Appl Environ Microbiol 75: 7537-7541.

Seebah, S., Fairfield, C., Ullrich, M.S., and Passow, U. (2014) Aggregation and sedimentation of Thalassiosira weissflogii (diatom) in a warmer and more acidified future ocean. PLoS One 9: e112379.

Seymour, J.R., Amin, S.A., Raina, J.B., and Stocker, R. (2017) Zooming in on the phycosphere: the ecological interface for phytoplankton-bacteria relationships. Nat Microbiol 2: 17065.

Smith, D.C., Steward, G.F., Long, R.A., and Azam, F. (1995) Bacterial mediation of carbon fluxes during a diatom bloom in a mesocosm. Deep Sea Research Part II: Topical Studies in Oceanography 42: 75-97.

Smriga, S., Fernandez, V.I., Mitchell, J.G., and Stocker, R. (2016) Chemotaxis toward phytoplankton drives organic matter partitioning among marine bacteria. Proc Natl Acad Sci U S A 113: 15761581.

Solomon, S., Qin, D., Manning, M., Marquis, M., Averyt, K., Tignor, M.M.B. et al. (2007) Climate Change 2007: The Physical Science Basis. Contribution of Working Group I to the Fourth Assessment Report of the Intergovernmental Panel on Climate Change. Cambridge University Press, Cambridge, UK; New York, NY, USA.

Stryhanyuk, H., Calabrese, F., Kummel, S., Musat, F., Richnow, H.H., and Musat, N. (2018) Calculation of Single Cell Assimilation Rates From SIP-NanoSIMS-Derived Isotope Ratios: A Comprehensive Approach. Front Microbiol 9: 2342.

Tada, Y., Taniguchi, A., Nagao, I., Miki, T., Uematsu, M., Tsuda, A., and Hamasaki, K. (2011) Differing growth responses of major phylogenetic groups of marine bacteria to natural phytoplankton blooms in the western North Pacific Ocean. Appl Environ Microbiol 77: 4055-4065. 
Teeling, H., Fuchs, B.M., Becher, D., Klockow, C., Gardebrecht, A., Bennke, C.M. et al. (2012) Substrate-controlled succession of marine bacterioplankton populations induced by a phytoplankton bloom. Science 336: 608-611.

von Scheibner, M., Dorge, P., Biermann, A., Sommer, U., Hoppe, H.G., and Jurgens, K. (2014) Impact of warming on phyto-bacterioplankton coupling and bacterial community composition in experimental mesocosms. Environ Microbiol 16: 718-733.

Wohlers, J., Engel, A., Zollner, E., Breithaupt, P., Jurgens, K., Hoppe, H.G. et al. (2009) Changes in biogenic carbon flow in response to sea surface warming. Proc Natl Acad Sci U S A 106: 70677072 .

Yvon-Durocher, G., Caffrey, J.M., Cescatti, A., Dossena, M., del Giorgio, P., Gasol, J.M. et al. (2012) Reconciling the temperature dependence of respiration across timescales and ecosystem types. Nature 487: 472-476. 


\section{Figure legends}

Figure 1. (A) Bacterial community composition in the particle-associated fraction ( $>3 \mu \mathrm{m}$ pore-size filters) expressed as percentage of total reads. Monthly in situ values of Chl a concentration and temperature are showed with a green dashed line and a black line respectively. (B) Bacterial community composition as percentage of total reads for the free-living fraction (fraction collected between $3 \mu \mathrm{m}$ and $0.22 \mu \mathrm{m}$ pore-size filters).

Figure 2. Abundance of microphytoplankton cells (lines), total heterotrophic bacteria (quantified by epifluorescence microscope using DAPI staining) and the two taxonomic groups (quantified by CARDFISH) in the free-living (A, B, C) and microphytoplankton-associated fractions (D, E, F) during the experimental incubations of January, February and March 2014 at ambient temperature. Note that the scale of the $y$ axis differs in the incubations of March (C,F).

Figure 3. Microphytoplankton (left panel) and total heterotrophic bacteria (middle panel) abundances at the end of the experiments of January, February and March. The right panel shows the abundance of Flavobacteria and Rhodobacteraceae in the free-living and microphytoplankton-associated fractions for the three temperature treatments. Incubation times differ for each incubation (132 h for January, $108 \mathrm{~h}$ for February and $12 \mathrm{~h}$ for March). Amb. T refers to ambient temperature, Cold to $3^{\circ} \mathrm{C}$ below ambient temperature and Warm to $3^{\circ} \mathrm{C}$ above ambient temperature. Error bars indicate standard deviation.

Figure 4. Images showing Flavobacteria (upper panels) and Rhodobacteraceae (lower panels) cells under epifluorescence microscopy (A, B) and their respective nanoSIMS image of atomic percent enrichment (APE) of ${ }^{13} \mathrm{C}(\mathrm{C}, \mathrm{D})$ and ${ }^{15} \mathrm{~N}(\mathrm{E}, \mathrm{F})$, indicating cell-specific isotopic uptake over the natural abundance of each isotope. White scale-bars equal $3 \mu \mathrm{m}$. 
Figure 5. Boxplots of carbon (A) and nitrogen (B) assimilation rates in the microphytoplanktonassociated fraction of Flavobacteria and Rhodobacteraceae at each temperature treatment and total carbon (C) and nitrogen (D) assimilation. Amb. $\mathrm{T}$ refers to ambient temperature, Cold to $3^{\circ} \mathrm{C}$ below ambient temperature and Warm to $3^{\circ} \mathrm{C}$ above ambient temperature. Error bars indicate standard deviation. 
Figure 1

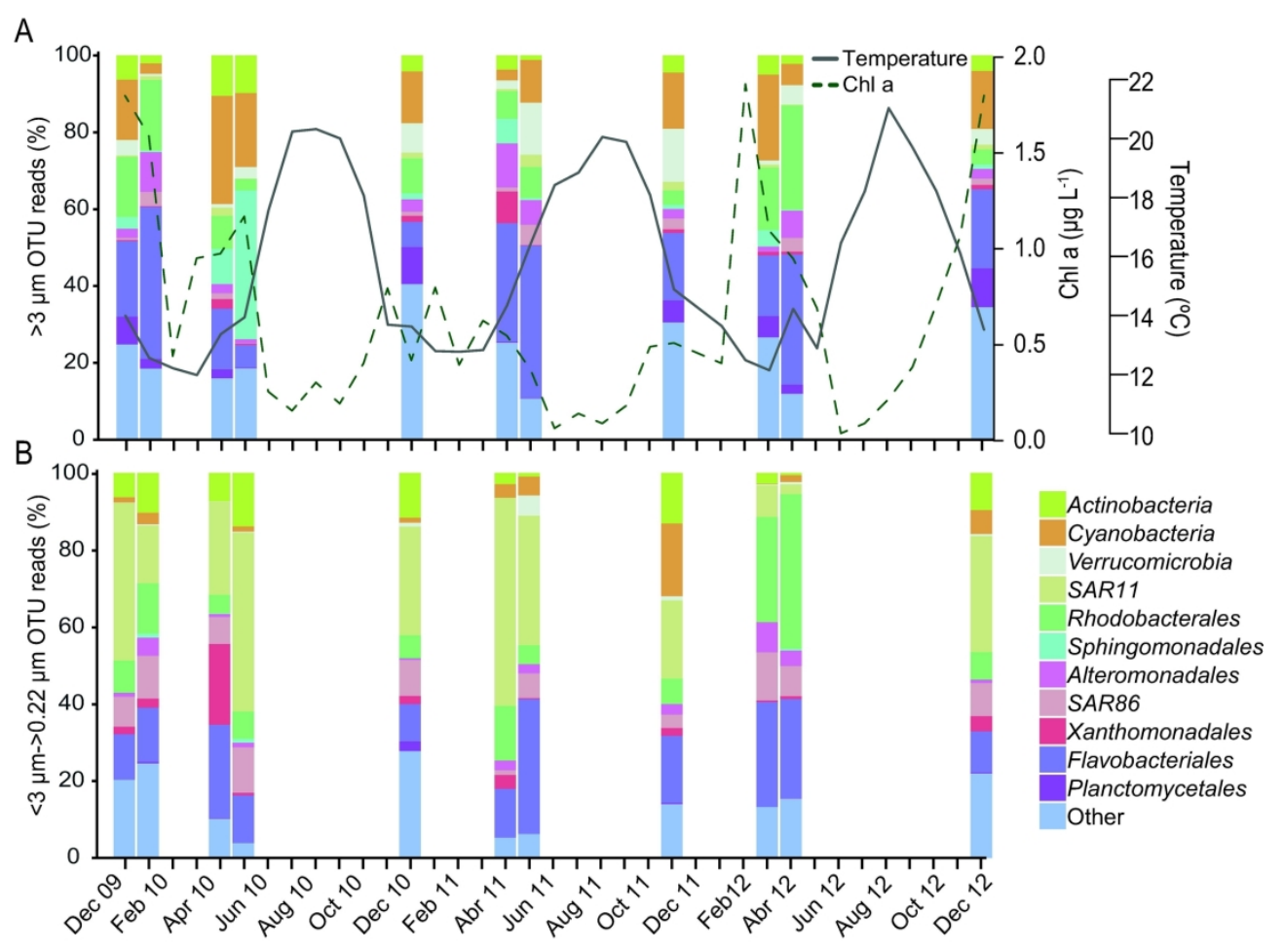

This article is protected by copyright. All rights reserved. 
Figure 2
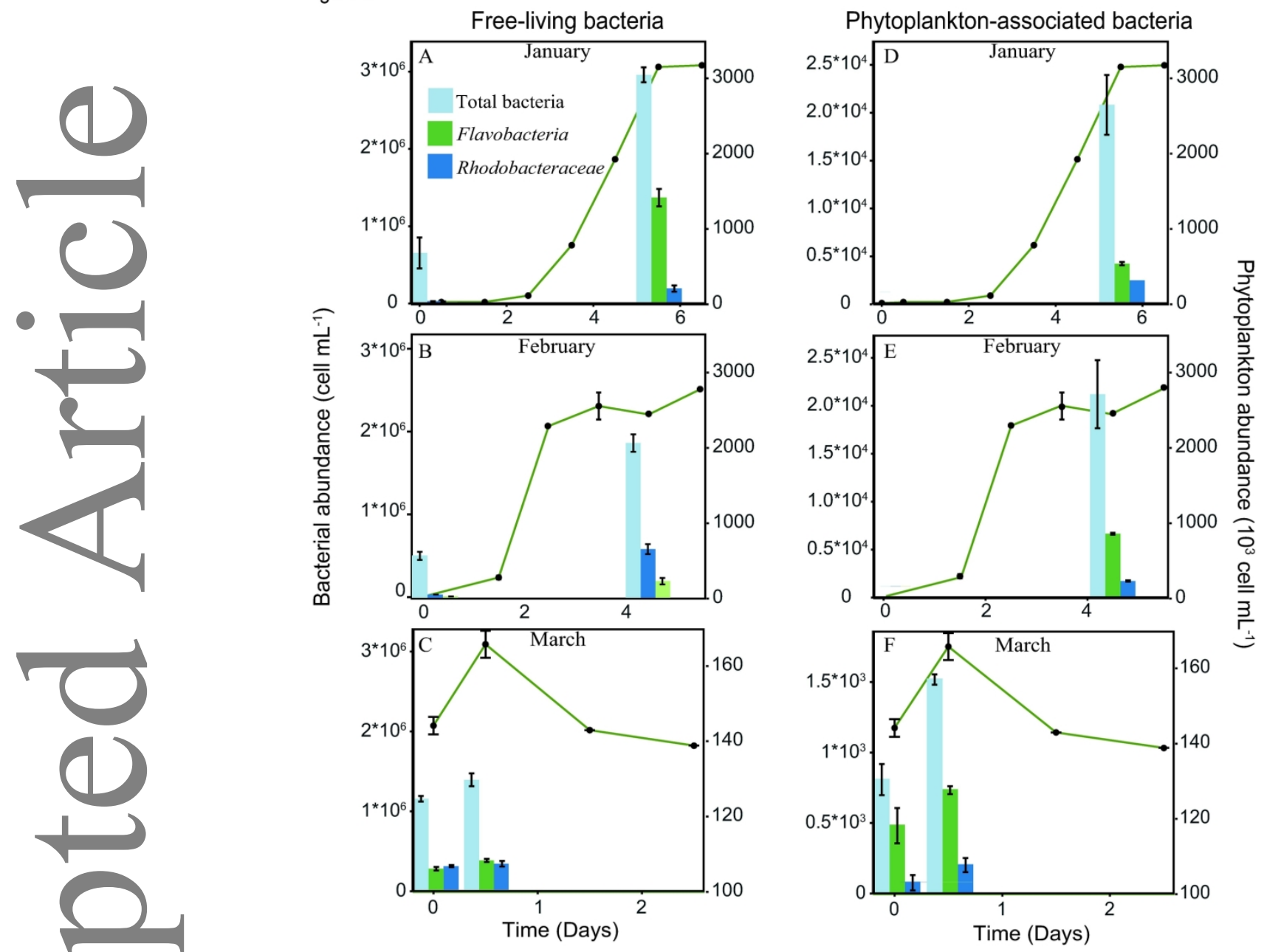

This article is protected by copyright. All rights reserved. 
Figure 4
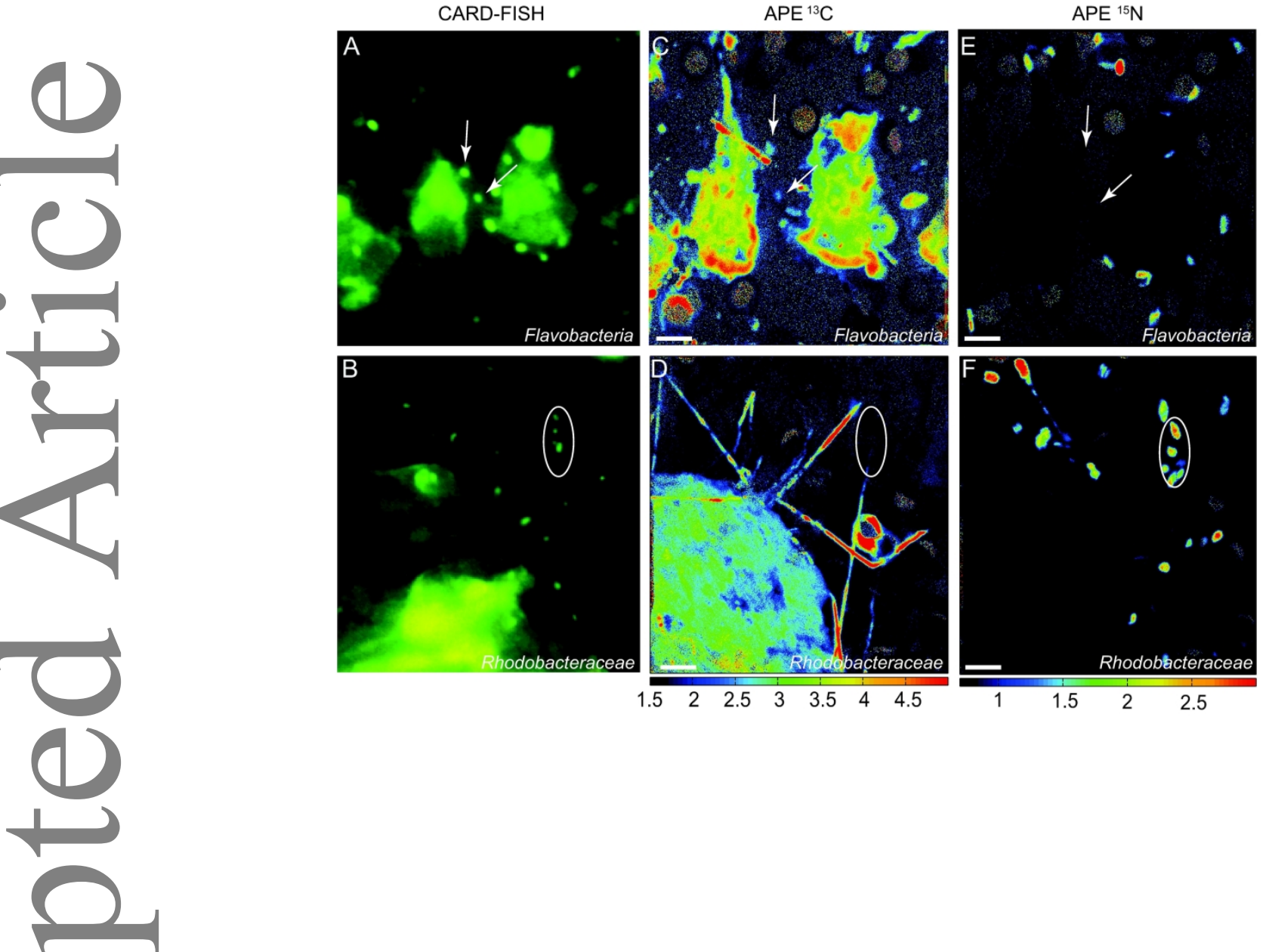

(1)

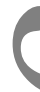

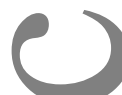


Figure 5
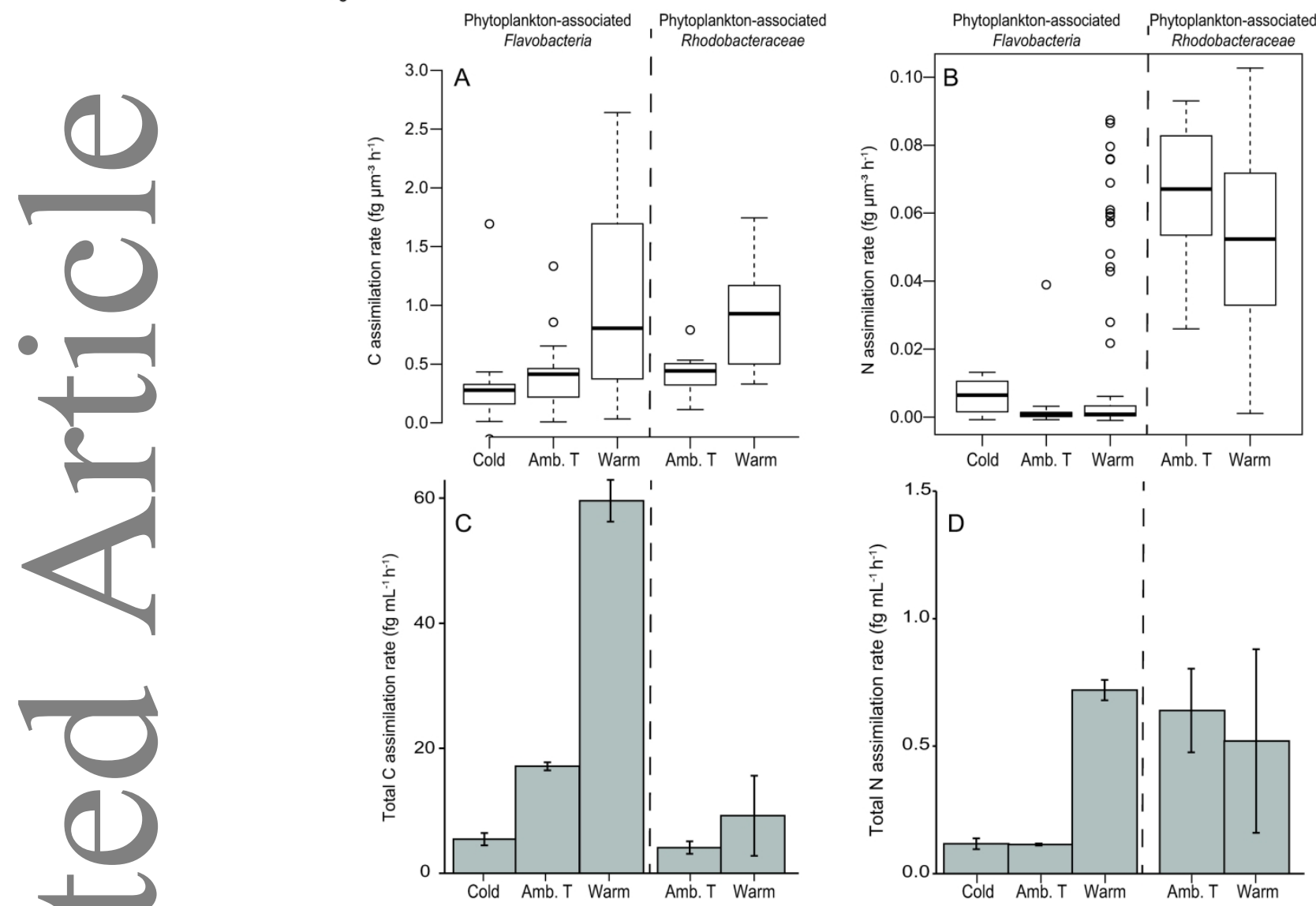

This article is protected by copyright. All rights reserved. 